We agree with Skidmore and Mawson that the persistence of serum IFN- $\alpha$ may predict the development of AIDS in individuals exposed to HIV. Furthermore serum IFN- $\alpha$ is correlated with a marked deficiency of leucocyte IFN- $\alpha$ production in patients with AIDS or ARC. ${ }^{3}$ The diminished capacity of endogenous IFN production may be responsible for the AIDS patients' susceptibility to opportunistic infections.

Institute of Microbiology,

Ludwigsburg Hospital,

7140 Ludwigsburg, West Germany

J. ABB

1. Bumovici-Klein $\mathrm{E}$, Lange $M$, Klein RJ, et al Long-term follow-up of serum interferon and its acrd stability in a group of homosexual men AIDS Res 1986, 2 $99-108$

2 Abb J. Comparative determination of serum interferon alpha in patients at risk for AIDS by bioassay and radiormmunoassay Proc Int Symp Impact Biotechnology Diagnostzcs 1985104 (abstr)

3 Abb J, Kochen $M$, Demhardt F. Interferon production in male homosexuals with AIDS or generalized lymphadenoparhy Infection 1984, 12: 240-42.

\section{IMMUNOBLOT TEST WITH RECOMBINANT HIV ANTIGENS}

SIR,-Confirmation of a positive anti-HIV screening test result is usually done by western blot (WB). Virus grown in tissue culture is disrupted and viral proteins are separated by gel electrophoresis and transferred to nitrocellulose paper. Attachment of serum antibody to the paper at characteristic sites indicates specific antibody against viral proteins. However, the conventional WB has disadvantages: $(a)$ it is expensive and time-consuming to produce in tissue culture the large amount of virus needed; ( $b$ ) HIV cultivation can only be done in special laboratories; (c) the concentration and relative amount of viral proteins may vary considerably in different antigen preparations; (d) the diagnostically most important envelope protein gp 41 migrates as a diffuse band; and (e) false-positive reactions may occur. ${ }^{1-3}$ The modification described here does not have these disadvantages.

We use three recombinant proteins encoded by pUC-vectors and produced in Escherichia coli-namely, proteins exhibiting antigenic epitopes of p24 (molecular weight $33 \mathrm{kD}$ ) and gp $41(20$ $\mathrm{kD})$ and a fusion protein of both $(47 \mathrm{kD})$. Without purification $E$ col lysates were subjected to SDS-PAGE and proteins were transferred to nitrocellulose paper strips with three lanes. Because crude bacterial lysates were used the background reaction in the modified WB is significant but testing of sera on three lanes differing only in the presence of one virus-encoded protein ensures specificity: non-specific reactions with bacterial lysates can be seen in all three lanes, whereas strong HIV-1 specific reactions for anti-p24 and anti-gp41 are found only once in each lane at a characteristic position (figure).

All three recombinant proteins are expressed without bacterial fusion proteins to avoid cross-reaction with antibody to bacterial proteins. We chose $\mathrm{p} 24$ because antibody to this protein seems to appear earliest after HIV infection, gp41 because antibody to this protein is the most specific for HIV-1 infection, and the fusion protein $\mathrm{gp} 41 / \mathrm{p} 24$ to provide independent confirmation and an opportunity for blot interpretation where the background staining in the other two lanes was heavy.

We evaluated the test on sera chosen from among routine diagnostic specimens and on United States-derived plasma pools.

46 sera were tested, with the following results:

$\begin{array}{ll}\text { Conventional WB } & \text { Recombinant WB } \\ 15 \text { positive } & 15 \text { positive (ant1-p24 and anti- } \\ & \text { gp } 41 \text { ) } \\ 16 \text { ? positive (no anti-gp41) } & 8 \text { positive (anti-gp41, some also } \\ & \text { ant1-p24); } 8 \text { negative for } \\ & \text { anti-gp41 } \\ 15 \text { negative } & 13 \text { negative; } 2 \text { positive (antl- } \\ & \text { gp } 41)\end{array}$

Thus in this panel of 46 sera all conventional WB positive samples were confirmed; the modified WB resulted in no "? positive" results and seemed to resolve all 16 ? positive sera on conventional WB; and 2 conventional WB results were false negatives (both coming from
A B C
A B C
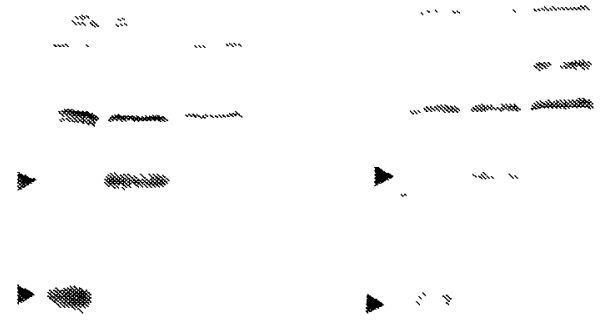

Reactivity in recombinant blot test of 2 sera lacking anti-gp41 and designated ? positive on conventional WB.

Bacterial lysates contained (A) recombinant p24, (B) recombinant fusion protein gp41/p24, and (C) recombinant gp41. HIV-1 specific reactions marked by arrows.

patients with AIDS). Among the 16 ? positive specimens 4 sera from two persons with recent seroconversion were identified by recombinant WB suggesting that $\mathrm{HIV}-1$ infection can be diagnosed earlier after seroconversion if the recombinant blot test rather than WB is used.

17 plasma pools have been tested:

\begin{tabular}{|c|c|c|c|}
\hline Date & $E I A^{\star}$ & Conventional $W B$ & Recombinant $W^{\prime} B$ \\
\hline $\begin{array}{l}\text { Aug to Dec, } \\
1985(n=10)\end{array}$ & $5+v e$ & $1+\mathrm{ve} ; 3 ?+\mathrm{ve} ;+1-\mathrm{ve}$ & $\begin{array}{c}4+\mathrm{ve}(\operatorname{anti}-\mathrm{gp} 41 \\
\text { not anti-p24) }\end{array}$ \\
\hline $\begin{array}{c}1986-87 \\
(n=7)\end{array}$ & $1+$ ve & 7 ?+vet & $\begin{array}{l}7 \text {-ve (neither } \\
\text { anti-gp41 nor } \\
\text { ant1-p24) }\end{array}$ \\
\hline
\end{tabular}

* Recombinant enzyme immunoassay (Abbott).

tPositive had reactivity to $\mathrm{p} 24, \mathrm{p} 31, \mathrm{gp} 41, \mathrm{p} 51, \mathrm{p} 55$, and $\mathrm{p} 66$. ? positives had reactivity to $\mathrm{p} 66$, to $\mathrm{p} 31$ and to $\mathrm{p} 51$, and to $\mathrm{p} 51$

t? posttives had reactivity to $\mathrm{p} 55$ ( 5 samples), to $\mathrm{p} 51$ (1), and to p24 and p55(1)

The results suggest that pooled plasma frequently exhibits non-specific reactivity to $\mathrm{p} 55$ or $\mathrm{p} 51$. However, the positive results for anti-gp 41 found in recombinant blot tests in pools from 1985 are probably specific.

These findings indicate that the recombinant blot test is very sensitive for the detection of anti-gp41. This is an important advantage since many specimens that are positive in a screening test are ? positive in conventional WB because no anti-gp41 can be demonstrated.

M. MOTZ

E. SOUTSCHEK-BAUER

G. G. FRÖSNER

L. GưrTLER

Max von Pettenkofer Institute,

M. SCHALI

Universiry of Munich,

H. WOLF

1. Biberfeld G, Bredberg-Raden U, Bottinger B, et al Blood donor sera with false-positive western blot reactions to human immunodeficiency virus. Lancet 1986; 11. 289-90.

2 Van der Poel CL, Reesnk HW, Tersmette Th, Lelie PN, Huisman H, Miedema F. Blood donations reactive for HIV in Western blot, but non-infective in culture and recipients of blood. Lancet 1986; 11: 752-54.

3. Courouce A-M, Muller J-Y, Richard D. False-positive Western blot reactions to human immunodeficiency virus in blood donors. Lancet 1986, 11. 921-22.

4 Yanisch-Perron $C_{y}$ Vieira J, Messing J Improved M13 phage cloning vectors and host strains: Nucleonde sequences of M13mpl 8 and pUC19 vectors Gene 1985, 33 103-19. 